\title{
Metabolic and hormonal effects of glucagon infusion in erythroblastotic infants
}

\author{
R. D. G. MILNER, S. K. CHOUKSEY, and R. ASSAN \\ From the Department of Child Health, University of Manchester, and the Faculté de Médecine de Paris, France
}

\begin{abstract}
Milner, R. D. G., Chouksey, S. K., and Assan, R. (1973). Archives of Disease in Childhood, 48, 885. Metabolic and hormonal effects of glucagon infusion in erythroblastotic infants. 10 or $50 \mu$ g glucagon was added to the bottle of donor blood, preserved with acid citrate and dextrose, used for exchange transfusion of erythroblastotic infants. The effects of the glucagon infusion on plasma glucose, insulin, growth hormone (GH), and glucagon were measured during the transfusion and for 60 minutes thereafter, and were compared with transfusions in which no addition was made to the donor blood. Both doses of glucagon produced similar effects: higher mean plasma glucose and insulin levels during the transfusion, but no significant change in plasma growth hormone levels. Transfusion with glucagonenriched blood had no effect on the net balance of glucose or growth hormone, but caused a negative insulin balance twice as big as that occurring in the control group.

At the end of the control transfusions the mean plasma glucagon was $248 \mathrm{pg} / \mathrm{ml}$ and this did not change significantly in the next 60 minutes. When 10 or $50 \mu \mathrm{g}$ glucagon was added to the donor blood the end-transfusion mean plasma glucagon concentrations were 1302 and $3975 \mathrm{pg} / \mathrm{ml}$, respectively. Glucagon disappeared rapidly from plasma for 5 to 10 minutes and then more slowly at the rate of 0.5 to $1.0 \%$ per minute for the next 50 minutes. The range of glucose disappearance rates in the 60 minutes after transfusion $(0 \cdot 40-2 \cdot 13 \% / \mathrm{min})$ was similar in all three groups, but the infants receiving glucagon-enriched blood had higher blood glucose levels for a given glucose disappearance rate. In each group there was a highly significant negative correlation between the 60-minute plasma glucose level and the glucose disappearance rate.

It is concluded that the addition of 10 or $50 \mu \mathrm{g}$ glucagon to the bottle of donor blood used for exchange transfusion may have a protective effect against post-transfusion hypoglycaemia. Measurement of the blood glucose level 60 minutes after the transfusion has both diagnostic and prognostic value in detecting hypoglycaemia.
\end{abstract}

Glucagon stimulates hepatic glycogenolysis and insulin secretion. Recently, published reports have noted the beneficial effects of glucagon on cardiac function (Parmley, Glick, and Sonnenblick, 1968; Brogan, Kozonis, and Overy, 1969; Manchester et al., 1970). Glucagon may therefore have a therapeutic place in the management of the erythroblastotic infants in whom heart failure is a common cause of death (Van Praagh, 1961). Since these babies hypersecrete insulin, it is apparent that glucagon might also make them hypoglycaemic.

The present study was undertaken to measure the metabolic and hormonal effects of glucagon in

Received 4 April 1973. infants undergoing exchange transfusions to determine if any undesirable metabolic consequence might preclude the therapeutic use of the hormone as a cardiac stimulant in this procedure.

\section{Patients and methods}

42 term newborn infants were studied. They were of normal weight for gestational age and suffered from mild to moderate erythroblastosis fetalis due to rhesus incompatibility. Results from 10 of the infants were reported earlier (Milner et al., 1972). Certain clinical details are presented in Table $I$.

Exchange transfusions were performed using blood preserved with acid citrate and glucose (ACD) as described previously (Milner et al., 1972). Immediately 
TABLE I

Clinical details of infants studied

\begin{tabular}{|c|c|c|c|c|c|c|}
\hline \multirow{2}{*}{$\begin{array}{l}\text { Type and no. of } \\
\text { transfusions }\end{array}$} & \multicolumn{2}{|c|}{$\begin{array}{l}\text { No. and sex of } \\
\text { patients }\end{array}$} & & \multirow{2}{*}{$\begin{array}{l}\text { Mean } \pm \text { SEN } \\
\begin{array}{l}\text { Postnatal } \\
\text { age (hr) }\end{array}\end{array}$} & \multicolumn{2}{|l|}{ (range) } \\
\hline & $\mathbf{M}$ & $\mathbf{F}$ & Birthweight (g) & & $\begin{array}{l}\text { Time from } \\
\text { last meal } \\
\text { (min) }\end{array}$ & $\begin{array}{l}\text { Rate of } \\
\text { transfusion } \\
(\mathrm{ml} / \mathrm{min})\end{array}$ \\
\hline $\begin{array}{l}\text { ACD }(25) \\
A C D+10 \mu g \text { glucagon }(15) \\
A C D+50 \mu g \text { glucagon }(10)\end{array}$ & $\begin{array}{r}11 \\
6 \\
4\end{array}$ & $\begin{array}{r}13 \\
6 \\
2\end{array}$ & $\begin{array}{c}3022 \pm 130 \\
(2250-4020) \\
2800 \pm 144 \\
(2250-3820) \\
3150 \pm 117 \\
(2550-3570)\end{array}$ & $\begin{array}{c}37 \pm 7 \\
(3-93) \\
36 \pm 10 \\
(4-126) \\
32 \pm 7 \\
(2-170)\end{array}$ & $\begin{array}{l}221 \pm 15 \\
(60-480) \\
198 \pm 16 \\
(60-300) \\
109 \pm 22 \\
(72-210)\end{array}$ & $\begin{array}{l}5 \cdot 3 \pm 0 \cdot 2 \\
(3 \cdot 7-7 \cdot 3) \\
5 \cdot 5 \pm 0 \cdot 3 \\
(4 \cdot 2-8 \cdot 1) \\
6 \cdot 4 \pm 0 \cdot 3 \\
(5 \cdot 1-8 \cdot 0)\end{array}$ \\
\hline
\end{tabular}

ACD, blood preserved with acid citrate and glucose (Milner et al., 1972).

before some transfusions, 10 or $50 \mu \mathrm{g}$ glucagon (Eli Lilly) was added to the bottle of donor blood and mixed by inversion. The three types of transfusions are referred to as (i) ACD or control transfusions, (ii) ACD $+10 \mu \mathrm{g}$ glucagon, and (iii) $\mathrm{ACD}+50 \mu \mathrm{g}$ glucagon. The infant was left in positive balance at the end of the transfusion so that the removal of blood samples in the following 60 minutes would produce the desired final haemodynamic balance. The end of the transfusion was defined as time 0 . The umbilical venous catheter was left in place, flushed with heparinized saline (10 units $/ \mathrm{ml}$ ), and blood samples were withdrawn from it at $5,10,20,30,40$, and 60 minutes. The total volume of these samples did not exceed $20 \mathrm{ml}$.

All blood was collected in chilled tubes containing 20 mg di-sodium ethylene diamine tetra-acetate and 4300 units kallikrein inhibitor (aprotinin) per $10 \mathrm{ml}$ blood. Plasma was separated by centrifugation within 10 minutes and stored at $4{ }^{\circ} \mathrm{C}$ or $-20^{\circ} \mathrm{C}$ until analysed for glucose or insulin, glucagon, and growth hormone $(\mathrm{GH})$ concentrations, respectively. Plasma glucagon concentrations were assayed at several dilutions and no effect of bilirubin on the assay was detected. Results were calculated and expressed as described previously (Milner et al., 1972). Glucose disappearance rates $\left(K_{t}\right)$ were calculated as described by Greville (1943).

\section{Results}

During transfusion. The donor blood in the three types of transfusions had similar plasma insulin and GH concentrations (Table II). The mean plasma glucose concentration in the transfusions with $\mathrm{ACD}+10 \mu \mathrm{g}$ glucagon was fortuitously higher than that in the other two groups. The addition of 10 or $50 \mu \mathrm{g}$ glucagon to the donor blood raised the mean $( \pm S E)$ plasma glucagon con-

\section{TABLE II}

Plasma concentrations ( $\pm S E$ ) of glucose, insulin, $G H$, and glucagon during exchange transfusion with 3 different types of donor blood

\begin{tabular}{|c|c|c|c|c|c|c|}
\hline & Donor & $0 \mathrm{ml}$ & $100 \mathrm{ml}$ & $200 \mathrm{ml}$ & $300 \mathrm{ml}$ & $400 \mathrm{ml}$ \\
\hline $\begin{array}{l}\text { Glucose }(\mathrm{mg} / 100 \mathrm{ml}) \\
\text { ACD } \\
\text { ACD }+10 \mu \mathrm{g} \text { glucagon } \\
\text { ACD }+50 \mu \mathrm{g} \text { glucagon } \\
\text { Insulin }(\mu U / \mathrm{ml})\end{array}$ & $\begin{array}{l}430 \pm 12(15) \\
470 \pm 7(10)^{\star} \\
418 \pm 13(15)\end{array}$ & $\begin{array}{l}70 \pm 4(15) \\
72 \pm 3(10) \\
61 \pm 2(15)\end{array}$ & $\begin{array}{l}120 \pm 4(15) \\
153 \pm 6(10) \dagger \\
131 \pm 6(15)\end{array}$ & $\begin{array}{l}143 \pm 6(15) \\
172 \pm 5(10) \dagger \\
159 \pm 6(15)\end{array}$ & $\begin{array}{l}154 \pm 5(15) \\
185 \pm 6(10) \dagger \\
175 \pm 6(15)^{\star}\end{array}$ & $\begin{array}{l}159 \pm 5(15) \\
195 \pm 9(10) \dagger \\
185 \pm 6(15) \dagger\end{array}$ \\
\hline $\begin{array}{l}\text { ACD } \\
\text { ACD }+10 \mu g \text { glucagon } \\
\text { ACD }+50 \mu g \text { glucagon } \\
G H(n g / m l)\end{array}$ & $\begin{array}{l}19 \pm 2(15) \\
21 \pm 2(10) \\
23 \pm 3(15)\end{array}$ & $\begin{array}{l}26 \pm 6(15) \\
29 \pm 5(10) \\
25 \pm 6(15)\end{array}$ & $\begin{array}{l}48 \pm 8(15) \\
85 \pm 17(10)^{\star} \\
78 \pm 12(15)^{\star}\end{array}$ & $\begin{array}{c}53 \pm 6(15) \\
114 \pm 19(10) \dagger \\
87 \pm 15(15)\end{array}$ & $\begin{array}{l}58 \pm 10(15) \\
89 \pm 14(10) \\
92 \pm 19(15)\end{array}$ & $\begin{array}{l}66 \pm 14(15) \\
81 \pm 13(10) \\
92 \pm 20(15)\end{array}$ \\
\hline $\begin{array}{l}\text { ACD } \\
\text { ACD }+10 \mu g \text { glucagon } \\
\text { ACD }+50 \mu g \text { glucagon } \\
\text { Glucagon }(p g / \mathrm{ml})\end{array}$ & $\begin{array}{l}2 \cdot 3 \pm 0 \cdot 4(15) \\
3 \cdot 5 \pm 0 \cdot 3(10) \\
2 \cdot 5 \pm 0 \cdot 2(15)\end{array}$ & $\begin{array}{l}34 \pm 5(15) \\
71 \pm 20(10)^{\star} \\
32 \pm 4(15)\end{array}$ & $\begin{array}{l}38 \pm 7(15) \\
59 \pm 14(10) \\
33 \pm 3(15)\end{array}$ & $\begin{array}{l}53 \pm 10(15) \\
73 \pm 17(10) \\
67 \pm 9(15)\end{array}$ & $\begin{array}{l}64 \pm 11(15) \\
91 \pm 17(10) \\
92 \pm 15(15)\end{array}$ & $\begin{array}{l}72 \pm 12(15) \\
89 \pm 14(10) \\
92 \pm 16(15)\end{array}$ \\
\hline $\begin{array}{l}\text { ACD } \\
\text { ACD }+10 \mu \mathrm{g} \text { glucagon } \\
\text { ACD }+50 \mu \mathrm{g} \text { glucagon }\end{array}$ & $\begin{array}{c}80 \pm 10(13) \\
7990 \pm 1320(10) \ddagger \\
29680 \pm 1600(15) \ddagger\end{array}$ & 二 & 二 & - & - & $\begin{array}{c}248 \pm 33(13) \\
1302 \pm 139(9) \ddagger \\
3975 \pm 315(14) \ddagger\end{array}$ \\
\hline
\end{tabular}

Note: No. of observations in parentheses. Levels of significance for comparison with transfusions in which $\mathrm{ACD}$ blood was used : $\star_{\mathrm{P}}<0.05$, $+\mathrm{P}<0 \cdot 01, \mp \mathrm{P}<0 \cdot 001$. 
centration from $80 \pm 10 \mathrm{pg} / \mathrm{ml}$ to $7990 \pm 1320 \mathrm{pg} / \mathrm{ml}$ and $29,680 \pm 1600 \mathrm{pg} / \mathrm{ml}$, respectively. In the infants receiving ACD transfusions the plasma glucagon level after $400 \mathrm{ml}$ was $248 \pm 33 \mathrm{pg} / \mathrm{ml}$. In the transfusions performed with glucagon-enriched blood the levels were 5 and 16 times higher. The plasma glucose levels in the ACD $+10 \mu \mathrm{g}$ glucagon transfusions were significantly higher than those in the ACD transfusions from the $100 \mathrm{ml}$ point onwards, whereas there was a significant difference in the ACD +50 $\mu \mathrm{g}$ glucagon transfusions in the 300 and $400 \mathrm{ml}$ samples only. The difference may have been partly due to the higher donor blood glucose concentration in the $\mathrm{ACD}+10 \mu \mathrm{g}$ glucagon transfusions. On the other hand, there was no significant linear correlation between the donor plasma glucose and the maximum plasma glucose in the infant during transfusion in any of the three groups. In both types of glucagon-enriched transfusion there was a higher plasma insulin level in the $100 \mathrm{ml}$ sample than in the ACD transfusions. The difference persisted in the $200 \mathrm{ml}$ sample of the $\mathrm{ACD}+10 \mu \mathrm{g}$ glucagon transfusions, but thereafter similar plasma insulin levels were observed in all three types of transfusion. The only significant difference in plasma GH concentration was observed in the infants receiving transfusions with $A C D+10$ $\mu$ g glucagon who had a higher mean plasma $G H$ concentration at the start of the procedure.

The similarity of the effect of the two doses of glucagon on the plasma concentrations of glucose, insulin, and GH enabled results from the two groups to be pooled for the calculation of mean changes in plasma concentration (Table III). In this analysis results were included from $10 \mathrm{ACD}$ transfusions performed earlier under comparable conditions. Glucagon caused a sustained rise in plasma glucose throughout the transfusion which was associated with higher plasma insulin levels during most of the procedure. Glucagon did not cause any difference in plasma $\mathrm{GH}$ levels.

Calculation of the total amount of glucose infused and withdrawn showed very similar results in all three types of transfusion (Table IV). Glucagon caused a net loss of insulin nearly twice that occurring in the control transfusions but had no significant effect on $\mathrm{GH}$ balance.

After transfusion. At the start of the posttransfusion period the mean plasma glucagon levels in the three groups of infants differed considerably (Table V). No change occurred in the mean plasma glucagon level of the control group in the next 60 minutes. The mean plasma glucagon level of both groups receiving glucagon-enriched blood fell rapidly in the first 5 to 10 minutes and more slowly thereafter (Fig. 1). The initial rate of fall was similar in the two groups, being $13.9 \%$ per minute in the infants who had received $A C D+10 \mu \mathrm{g}$ glucagon transfusions and $15.8 \%$ per minute in those who had ACD $+50 \mu$ g glucagon transfusions. The subsequent disappearance rates were 0.5 and $1.0 \%$ per minute, respectively.

The mean plasma glucose of infants receiving $\mathrm{ACD}+50 \mu \mathrm{g}$ glucagon transfusions remained significantly higher than that of the control group until the 60 minute sample. The mean plasma glucose level of the infants who had received $\mathrm{ACD}+10 \mu \mathrm{g}$ glucagon transfusions were significantly raised at 5 and 10 minutes only. Hyperglycaemia and hyperglucagonaemia had no significant effect on plasma insulin and GH levels in the post-transfusion period. Mean plasma insulin levels in the ACD $+10 \mu \mathrm{g}$ glucagon group were similar to those in the control group, whereas those in the $\mathrm{ACD}+50 \mu \mathrm{g}$ glucagon group tended to be

TABLE III

Changes in plasma concentrations ( $\pm S E$ ) of glucose, insulin, and $G H$ during exchange transfusion using $A C D$ blood with or without glucagon

\begin{tabular}{|c|c|c|c|c|}
\hline & $100 \mathrm{ml}$ & $200 \mathrm{ml}$ & $300 \mathrm{ml}$ & $400 \mathrm{ml}$ \\
\hline $\begin{array}{l}\text { Glucose }(\mathrm{mg} / 100 \mathrm{ml}) \\
\text { ACD } \\
\text { ACD + glucagon } \\
\text { Insulin }(\mu \mathrm{U} / \mathrm{ml}) \\
\text { ACD } \\
\text { ACD + glucagon } \\
\text { GH }(n g / m l) \\
\text { ACD } \\
\text { ACD + glucagon }\end{array}$ & $\begin{array}{l}+48 \pm 2(25) \\
+74 \pm 4(25)^{\star} \\
+25 \pm 7(25) \\
+54 \pm 9(25) \\
+9 \pm 5(25) \\
+4 \pm 4(25) \dagger\end{array}$ & $\begin{array}{l}+69 \pm 4(25) \\
+99 \pm 4(25)^{\star} \\
+28 \pm 5(25) \\
+71 \pm 10(25)^{\star} \\
+23 \pm 7(25) \\
+22 \pm 10(25)\end{array}$ & $\begin{array}{l}+82 \pm 5(25) \\
+114 \pm 4(25)^{\star} \\
+35 \pm 8(25) \\
+64 \pm 11(25) \dagger \\
+39 \pm 10(25) \\
+44 \pm 11(25)\end{array}$ & $\begin{array}{l}+87 \pm 7(25) \\
+124 \pm 5(25)^{\star} \\
+45 \pm 8(23) \\
+65 \pm 13(25) \\
+48 \pm 14(23) \\
+43 \pm 12(25)\end{array}$ \\
\hline
\end{tabular}

Note: Figures for ACD transfusions are from the results of present study plus results of Milner et al. (1972). Figures for ACD + glucagon transfusions calculated from transfusions in which 10 or $50 \mu \mathrm{g}$ glucagon were added to donor blood. No. of observations in parentheses. Level of significance between the two types of transfusion: ${ }^{\star} P<0.001,+P<0.05$. 
TABLE IV

Total amount of metabolite or hormone infused or removed in 3 different types of transfusion

\begin{tabular}{|c|c|c|c|}
\hline \multirow[t]{2}{*}{ Hormone or metabolite } & \multicolumn{3}{|c|}{$\begin{array}{c}\text { Amount infused or removed } / \mathrm{kg} \text { body weight } \\
(\text { Mean } \pm \text { SEM })\end{array}$} \\
\hline & In & Out & Balance \\
\hline $\begin{array}{l}\text { Glucose }(m g) \\
\text { ACD }(25) \\
\text { ACD }+10 \mu g \text { glucagon (10) } \\
\text { ACD }+50 \mu g \text { glucagon (15) } \\
\text { Insulin }(m U) \\
\text { ACD }(25) \\
\text { ACD }+10 \mu g \text { glucagon (10) } \\
\text { ACD }+50 \mu g \text { glucagon (15) } \\
\text { GH }(\mu g) \\
\text { ACD }(25) \\
\text { ACD }+10 \mu g \text { glucagon (10) } \\
\text { ACD }+50 \mu g \text { glucagon (15) }\end{array}$ & $\begin{array}{l}252 \pm 14 \\
253 \pm 9 \\
267 \pm 17 \\
\\
1 \cdot 54 \pm 0 \cdot 19 \\
1 \cdot 13 \pm 0 \cdot 1 \\
1 \cdot 57 \pm 0 \cdot 25 \\
\\
0 \cdot 18 \pm 0 \cdot 27 \\
0 \cdot 36 \pm 0 \cdot 03 \\
0 \cdot 16 \pm 0 \cdot 16\end{array}$ & $\begin{array}{c}100 \pm 4 \\
103 \pm 5 \\
118 \pm 8 \\
3 \cdot 90 \pm 0 \cdot 37 \\
5 \cdot 39 \pm 0 \cdot 65 \\
6 \cdot 02 \pm 1 \cdot 08 \\
\\
4 \cdot 25 \pm 0 \cdot 44 \\
5 \cdot 00 \pm 1 \cdot 07 \\
5 \cdot 07 \pm 0 \cdot 63\end{array}$ & $\begin{array}{l}+156 \pm 12 \\
+151 \pm 5 \\
+149 \pm 14 \\
-2 \cdot 34 \pm 0 \cdot 43 \\
-4 \cdot 26 \pm 0 \cdot 67 \\
-4 \cdot 44 \pm 0 \cdot 98 \\
\\
-4 \cdot 07 \pm 0 \cdot 44 \\
-4 \cdot 65 \pm 1 \cdot 10 \\
-4 \cdot 90 \pm 0 \cdot 63\end{array}$ \\
\hline
\end{tabular}

Note: No. of observations in parentheses. Level of significance for comparison with transfusions in which ACD blood was used: $\star \mathrm{P}<0 \cdot 05$.

higher. Plasma GH levels were similar in all three groups.

Glucose disappearance rates $\left(\mathrm{K}_{\mathrm{t}}\right)$ were calculated for each infant. The mean $( \pm S E) K_{t}$ for the ACD transfusion group was $1 \cdot 30 \pm 0 \cdot 15$ (range $0 \cdot 40$ $1 \cdot 58$ ). This did not differ significantly from the mean value of the ACD $+10 \mu \mathrm{g}$ glucagon group, $1 \cdot 47 \pm 0 \cdot 17$ (range $0 \cdot 50-2 \cdot 13$ ), nor from that of the ACD $+50 \mu \mathrm{g}$ glucagon group, $1 \cdot 19 \pm 0 \cdot 21$ (range 0.59-1.93). In Fig. 2 plasma glucose levels 5 minutes after the transfusion are plotted as a scatterdiagram against $\mathrm{K}_{\mathrm{t}}$. There is no significant correlation between the two variables, but the higher plasma glucose concentrations in the infants who had received glucagon-enriched blood is apparent. In contrast, the plasma glucose 60 minutes after the transfusion correlated negatively with $K_{t}$ in both control and experimental groups (Fig. 3). The negative correlation between plasma glucose and $\mathrm{K}_{\mathrm{t}}$ is highly significant in both ACD transfusions $(\mathrm{r}=0.912, \mathrm{P}<0.001)$ and in glucagon-enriched transfusion $(r=0.878, P<0.001)$. No significant correlation between $\mathrm{K}_{\mathrm{t}}$ and 5- or 60-minute plasma insulin or GH levels was noted.

\section{Discussion}

The present study has shown that glucagon stimulates insulin secretion when added to the donor blood used in exchange transfusions. The increased secretion was manifest both as a rise in plasma concentration during the transfusion and as an increased net loss of insulin resulting from the procedure, but had no untoward effect as judged clinically or by the measurement of plasma glucose

Plasma concentrations ( $\pm S E$ ) of glucose, insulin, $G H$, and gluGagor

\begin{tabular}{|c|c|c|c|}
\hline & $0 \mathrm{~min}$ & $5 \mathrm{~min}$ & $10 \mathrm{~min}$ \\
\hline $\begin{array}{l}\text { Glucose }(\mathrm{mg} / 100 \mathrm{ml}) \\
\text { ACD } \\
\text { ACD }+10 \mu \mathrm{g} \text { glucagon } \\
\text { ACD }+50 \mu \mathrm{g} \text { glucagon } \\
\text { Insulin }(\mu \mathrm{U} / \mathrm{ml})\end{array}$ & $\begin{array}{l}159 \pm 5(15) \\
195 \pm 9(10) \dagger \\
185 \pm 6(15) \dagger\end{array}$ & $\begin{array}{l}127 \pm 5(10) \\
161 \pm 13(10)^{\star} \\
173 \pm 9(5) t\end{array}$ & $\begin{array}{l}116 \pm 6(10) \\
146 \pm 10(10)^{\star} \\
157 \pm 11(6)^{\star}\end{array}$ \\
\hline $\begin{array}{l}\text { ACD } \\
\text { ACD }+10 \mu \mathrm{g} \text { glucagon } \\
\text { ACD }+50 \mu \mathrm{g} \text { glucagon } \\
G H(n g / m l)\end{array}$ & $\begin{array}{l}66 \pm 14(15) \\
81 \pm 12(10) \\
92 \pm 20(15)\end{array}$ & $\begin{array}{c}107 \pm 29(10) \\
117 \pm 21(10) \\
99 \pm 26(6)\end{array}$ & $\begin{array}{r}90 \pm 17(10) \\
95 \pm 14(10) \\
116 \pm 27(6)\end{array}$ \\
\hline $\begin{array}{l}\text { ACD } \\
\text { ACD }+10 \mu \mathrm{g} \text { glucagon } \\
\text { ACD }+50 \mu \mathrm{g} \text { glucagon } \\
\text { Glucagon }(\mathrm{pg} / \mathrm{ml})\end{array}$ & $\begin{array}{l}72 \pm 12(15) \\
89 \pm 14(10) \\
92 \pm 16(15)\end{array}$ & $\begin{array}{l}79 \pm 12(10) \\
84 \pm 14(10) \\
86 \pm 25(5)\end{array}$ & $\begin{array}{l}80 \pm 14(10) \\
81 \pm 16(10) \\
85 \pm 20(6)\end{array}$ \\
\hline $\begin{array}{l}\text { ACD } \\
\text { ACD }+10 \mu g \text { glucagon } \\
\text { ACD }+50 \mu \mathrm{g} \text { glucagon }\end{array}$ & $\begin{array}{c}248 \pm 33(13) \\
1302 \pm 146(9) \ddagger \\
3975 \pm 327(14) \ddagger\end{array}$ & $\begin{array}{c}245 \pm 32(10) \\
689 \pm 128(10) \dagger \\
1776 \pm 277(6) \ddagger\end{array}$ & $\begin{array}{l}249 \pm 36(10) \\
506 \pm 65(10) t \\
804 \pm 33(7) \ddagger\end{array}$ \\
\hline
\end{tabular}




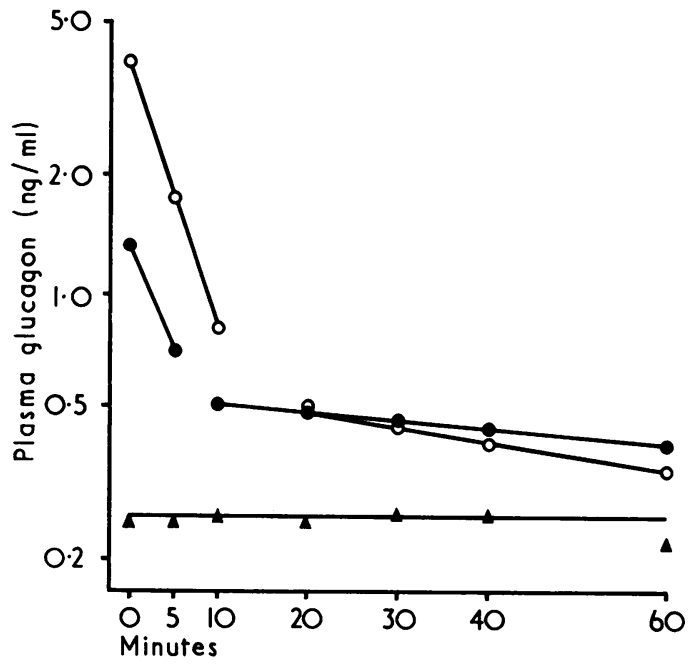

FIG. 1.-Mean plasma glucagon concentration after exchange transfusion in infants who received $A C D$ transfusions $\triangle, A C D+10 \mu g$ glucagon transfusions $\mathrm{O}$, or $A C D+50 \mu g$ glucagon transfusions 0 .

levels. Higher rises in plasma glucose occurred throughout the glucagon-enriched transfusions and persisted for $\mathbf{4 0}$ minutes afterwards in infants who had received $A C D+50 \mu \mathrm{g}$ glucagon transfusions. These changes were probably due to stimulation by glucagon of hepatic glycogenolysis coincident with the glucose infusion, since the net positive glucose balance in each of the three groups was similar.

The overall effect on glucose homoeostasis of adding glucagon to the donor blood may be best appreciated by considering the rate of glucose disappearance in the hour after the transfusion. The range of $K_{t}$ was similar in control and experimental groups, but for a given $K_{t}$ the 60 minute plasma glucose was higher in infants who had received glucagon-enriched blood (Fig. 3). The reason for this is not clear, since the infants receiving $A C D+50 \mu \mathrm{g}$ glucagon transfusions also had higher mean plasma insulin levels in the posttransfusion period. Hyperglucagonaemia persisted throughout the 60-minute period in both groups receiving glucagon-enriched blood and might have counteracted the action of insulin. Plasma GH levels remained raised in all three groups, suggesting that increased secretion of $\mathrm{GH}$ was not responsible for the similarity of the $K_{t}$ values. Though the results show a protective effect of glucagon against hypoglycaemia in the first hour after transfusion, they do not indicate if the protection would persist during the second and third hours when hypoglycaemia most commonly occurs (Schiff et al., 1971).

The close negative correlation between $K_{t}$ and the 60-minute post-transfusion plasma glucose level suggests that the measurement of the blood glucose concentration one hour after the transfusion has both diagnostic and prognostic value. The lower the blood glucose at this time the faster the rate of glucose disappearance and the more likely is the baby to become hypoglycaemic.

Glucagon stimulates GH secretion in normal newborn infants (Milner and Wright, 1967), but the infants who received glucagon-enriched donor blood did not secrete more GH than the control group. Increased GH secretion in ACD transfusions has been shown to be due in part to the glucose infusion and in part to other factors (Milner et al., 1972).

after exchange transfusion with 3 different types of donor blood

\begin{tabular}{|c|c|c|c|}
\hline $20 \mathrm{~min}$ & $30 \mathrm{~min}$ & $40 \mathrm{~min}$ & $60 \mathrm{~min}$ \\
\hline $\begin{array}{l}109 \pm 7(10) \\
125 \pm 10(10) \\
145 \pm 9(6)^{\star}\end{array}$ & $\begin{array}{c}97 \pm 6(10) \\
107 \pm 11(10) \\
132 \pm 9(6)^{\star}\end{array}$ & $\begin{array}{c}86 \pm 6(9) \\
93 \pm 10(10) \\
117 \pm 8(6)^{\star}\end{array}$ & $\begin{array}{l}78 \pm 6(10) \\
75 \pm 9(10) \\
94 \pm 10(6)\end{array}$ \\
\hline $\begin{array}{r}88 \pm 24(10) \\
77 \pm 15(10) \\
123 \pm 26(6)\end{array}$ & $\begin{array}{c}75 \pm 20(10) \\
61 \pm 14(10) \\
137 \pm 31(6)\end{array}$ & $\begin{array}{c}50 \pm 15(9) \\
54 \pm 15(10) \\
104 \pm 24(6)\end{array}$ & $\begin{array}{l}53 \pm 16(10) \\
59 \pm 19(10) \\
81 \pm 24(6)\end{array}$ \\
\hline $\begin{array}{l}73 \pm 12(10) \\
74 \pm 13(10) \\
78 \pm 18(6)\end{array}$ & $\begin{array}{l}67 \pm 13(10) \\
72 \pm 12(10) \\
80 \pm 16(6)\end{array}$ & $\begin{array}{l}62 \pm 12(9) \\
74 \pm 13(10) \\
81 \pm 16(6)\end{array}$ & $\begin{array}{l}64 \pm 13(10) \\
76 \pm 12(10) \\
96 \pm 15(6)\end{array}$ \\
\hline $\begin{array}{l}241 \pm 27(10) \\
497 \pm 61(10) \ddagger \\
488 \pm 57(6) \dagger\end{array}$ & $\begin{array}{l}258 \pm 27(10) \\
445 \pm 63(10) \dagger \\
428 \pm 49(7) \dagger\end{array}$ & $\begin{array}{l}252 \pm 28(9) \\
444 \pm 50(10) \dagger \\
391 \pm 40(7)^{\star}\end{array}$ & $\begin{array}{l}215 \pm 19(10) \\
393 \pm 52(10) \dagger \\
327 \pm 52(6)\end{array}$ \\
\hline
\end{tabular}

$1.01, \ddagger P<0.001$. 


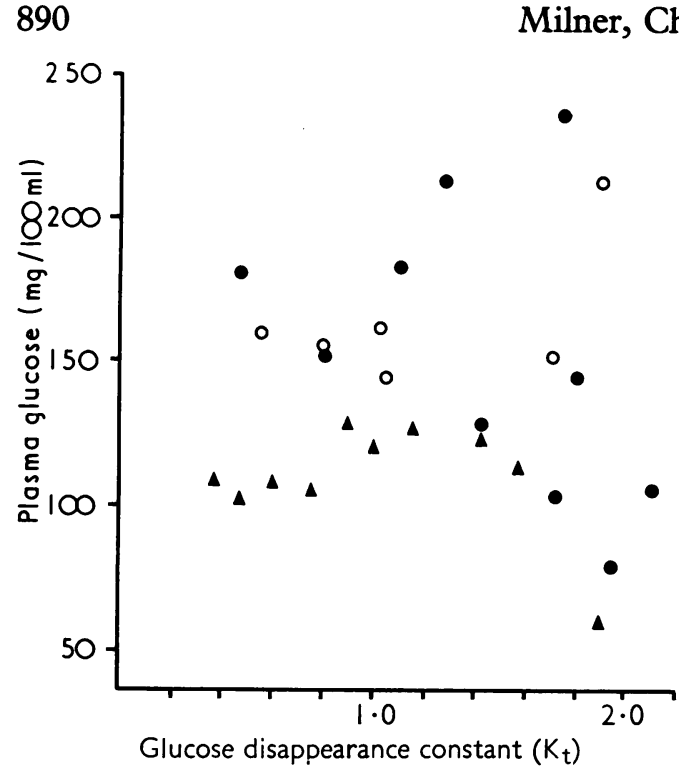

FIG. 2.-Scatterdiagram of plasma glucose 5 minutes after exchange transfusion plotted against $K_{\mathrm{t}}$. Symbols as in Fig. 1.

The failure of glucagon to increase $\mathrm{GH}$ secretion further suggests that $\mathrm{GH}$ release during an ACD transfusion may be occurring at a maximum rate. The persistence of high plasma GH levels for 60 minutes after the transfusion indicates that the hypersecretion of $\mathrm{GH}$ continues for some time.

The amount of glucagon added to the donor blood initially, $50 \mu \mathrm{g}$, was chosen empirically since it was known that glucagon is rapidly destroyed in the presence of blood (Heding, 1971; Assan, 1972). This proved to be the case, since the mean plasma glucagon level in the donor bottle at the start of the transfusion was $29.68 \mathrm{ng} / \mathrm{ml}$, whereas if the hormone had been undamaged the plasma concentration would have been in the order of 250 $\mathrm{ng} / \mathrm{ml}$. Further destruction of glucagon undoubtedly occurred in vitro during the transfusion since the mean plasma concentration in the infants at the end of the procedure was only $13 \%$ of that in the donor bottle. Similar results were obtained when $10 \mu \mathrm{g}$ glucagon was added to the donor blood. No explanation is apparent for the significantly lower mean plasma glucagon level in the donor ACD blood than that reported previously (Milner et al., 1972).

The disappearance of radioactive glucagon (Berson, Yalow, and Volk, 1957) or exogenous pancreatic glucagon (Assan, 1972) from the circulation in adults is rapid, and occurs at a similar rate to that observed in the first 10 minutes of the post-transfusion period. The subsequent

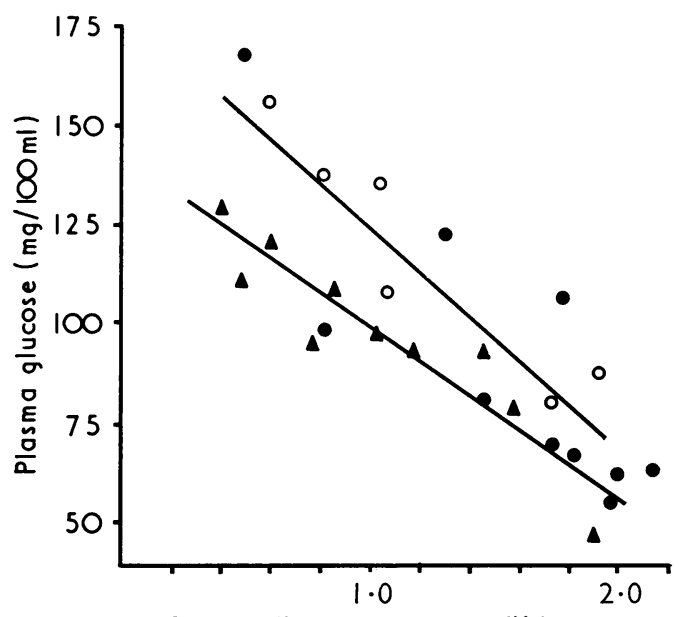

Glucose disappearance rate $\left(\mathrm{K}_{\mathrm{t}}\right)$

Fig. 3.-Scatterdiagram of plasma glucose 60 minutes after exchange transfusion plotted against $K_{\mathrm{t}}$. Symbols as in Fig. 1. The lower line shows the linear relation between plasma glucose and $K_{\mathrm{t}}$ in the ACD transfusions and the upper line the same relation in glucagon-enriched transfusions.

apparently slow disappearance of the hormone is open to different interpretations. It is possible that the initial rate of glucagon loss was unphysiological and due in part to hepatic and renal catabolism and excretion (Assan, 1972), whereas the slower subsequent rate of disappearance was physiological and indicated that the newborn infant has a reduced ability, as with many other substances, to catabolize glucagon. An alternative explanation is that the initial rate of loss was physiological and the subsequent apparent slow disappearance was due to the persistence of immunoreactive glucagon fragments in the serum (Heding, 1971). It is unlikely that the high plasma concentrations of glucagon from 20 to 60 minutes post-transfusion were due to endogenous glucagon secretion since the infants were both hyperglycaemic and hyperinsulinaemic, conditions known to suppress glucagon release (Müller et al., 1970).

When the effects of $50 \mu \mathrm{g}$ glucagon on plasma glucose and insulin had been shown, further transfusions were performed using $10 \mu \mathrm{g}$ to see if a different response occurred. The only significant difference between the two doses was that the infants receiving $50 \mu \mathrm{g}$ glucagon remained hyperglycaemic for longer after the transfusion ended. For this reason it may be suggested that the higher dose had a more beneficial clinical effect. 
We are grateful to Professor J. A. Davis for his encouragement, and to the Medical Research Council and British Diabetic Association for financial support. S.K.C. received personal support from the Research Grants Committee of the United Manchester Hospitals.

\section{REFERENCES}

Assan, R. (1972). In vivo metabolism of glucagon. In Glucagon, p. 47. Ed. by P. J. Lefebvre and R. H. Unger. Pergamon Press, Oxford.

Berson, S. A., Yalow, R. S., and Volk, B. W. (1957). In vivo and in vitro metabolism of insulin- $\mathrm{I}^{131}$ and glucagon- $\mathrm{I}^{131}$ in normal and cortisone-treated rabbits. Fournal of Laboratory and Clinical Medicine, 49, 331.

Brogan, E., Kozonis, M. C., and Overy, D. C. (1969). Glucagon therapy in heart-failure. Lancet, $1,482$.

Greville, G. D. (1943). The intravenous glucose tolerance equation. Biochemical fournal, 37, 17.

Heding, L. G. (1971). Radioimmunological determination of pancreatic and gut glucagon in plasma. Diabetologia, 7, 10.

Manchester, J. H., Parmley, W. W., Matloff, J. M., Leidtke, A. J., LaRaia, P. J., Herman, M. V., Sonnenblick, E. H., and Gorlin, R. (1970). Effects of glucagon on myocardial oxygen consumption and coronary blood flow in man and in dog. Circulation, 41, 579.
Milner, R. D. G., Fekete, M., Assan, R., and Hodge, J. S. (1972). Effect of glucose on plasma glucagon, growth hormone, and insulin in exchange transfusion. Archives of Disease in Childhood, 47, 179.

Milner, R. D. G., and Wright, A. D. (1967). Plasma glucose, nonesterified fatty acid, insulin and growth hormone response to glucagon in the newborn. Clinical Science, 32, 249.

Müller, W. A., Faloona, G. R., Aguilar-Parada, E., and Unger, R. H. (1970). Abnormal alpha-cell function in diabetes. Response to carbohydrate and protein ingestion. New England fournal of Medicine, 283, 109.

Parmley, W. W., Glick, G., and Sonnenblick, E. H. (1968). Cardiovascular effects of glucagon in man. New England fournal of Medicine, 279, 12.

Schiff, D., Aranda, J. V., Colle, E., and Stern, L. (1971). Metabolic effects of exchange transfusion. II. Delayed hypoglycemia following exchange transfusion with citrated blood. Fournal of Pediatrics, 79, 589

Van Praagh, R. (1961). Causes of death in infants with hemolytic disease of the newborn. Pediatrics, 28, 223.

Correspondence to Dr. R. D. G. Milner, Department of Child Health, St. Mary's Hospital, Hathersage Road, Manchester M13 0JH. 